\title{
비타민 $\mathrm{E}$ 강화콩 재배가 곤충다양성에 미치는 영향
}

\author{
오성덕 $^{1 \dagger} \cdot$ 서상재 $^{2 \dagger} \cdot$ 박수윤 $^{1} \cdot$ 이기종 ${ }^{3} \cdot$ 손수인 $^{1} \cdot$ 윤도 원 $^{1} \cdot$ 장안철 $^{1^{*}}$ \\ ${ }^{1}$ 농촌진흥청 국립농업과학원 생물안전성과, ${ }^{2}$ 경북대학교 농업생명과학대학 응용생명과학부, \\ ${ }^{3}$ 농촌진흥청 연구운영과
}

\section{Effects of Vitamin $\mathbf{E}$ enhanced transgenic soybean cultivation on insect divensity}

\author{
Sung-Dug $\mathrm{Oh}^{1 \dagger}$, SangJae $\mathrm{Suh}^{2 \dagger}$, Soo-Yun Park ${ }^{1}$, Kijong Lee ${ }^{3}$, Soo-In Sohn ${ }^{1}$, \\ Doh-Won Yun ${ }^{1}$, and Ancheol Chang ${ }^{{ }^{*}}$ \\ ${ }^{I}$ Department of Agricultural Biotechnology,NationalInstitute of Agricultural Sciences, Rural Development \\ Administration, Jeonju, 54874, Korea \\ ${ }^{2}$ School of Applied Biosciences, Kyungpook National University, Daegu, 41566, Korea \\ ${ }^{3} R \& D$ Coordination Division, Rural Development Administration, Jeonju 54875, Republic of Korea \\ ${ }^{\dagger}$ The first two authors contributed equally to this work
}

\begin{abstract}
This study was carried out to develop of environmental risk assessments and the biosafety guide for Vitamin E enhanced transgenic soybean at LMO (Living Modified Organism) isolation field. In LMO quarantine area of National Institute of Agricultural Sciences, insect species diversities and population densities on vitamin E enhanced transgenic soybean and non-GM soybeans (Willams 82 and Seoritae) were investigated. A total of 17,717 individuals of 77 species from 8 orders were collected in LMO isolation field. In three type soybeans field, total of 5,250 individuals in Vitamin E enhanced transgenic soybean, 5,510 individuals in Willams 82, and 6,957 individuals in Seoritae were collected, respectively. There was no difference between the population densities of insect pests, natural enemies and other insects on Vitamin E enhanced transgenic soybean and Willams 82, while natural enemies density on Seoritae was higher than on Vitamin E enhanced transgenic soybean, but insect pests density on Vitamin E enhanced transgenic soybean was higher. These results provided the insects diversity for risk assessment survey of Vitamin E enhanced transgenic soybean and suggested that the guideline could be useful to detect LMO crops.
\end{abstract}

Keywords : Biosafety, Vitamin E enhanced transgenic soybean, Insect diversity

\section{서 언}

동북아시아 지역이 기원지인 콩[Glycine max (L.) Merill]은 단백질, 식이섬유, 지질 등의 주요 영양 성분뿐만 아니라 이소플 라본 및 올리고당, 안토시아닌, 사포닌 등 다양한 기능성 성분을 함유하고 있어, 전 세계적으로 건강한 식생활을 위한 식품으로 수요와 소비가 계속 증가하고 있다(Lee et al. 2011a).

교배가 어렵거나 장기간이 소요되는 기존 전통 육종의 한계를

*Corresponding Author (E-mail: abychan@korea.kr, Tel: +82-63238-4711, Fax: +82-63-238-4704)

(Received on May 11, 2017. Accepted on July 12, 2017.)
극복하고자 1980년대 이후 생명공학기술을 이용하여 다양한 연구가 진행되고 있으며, 연구 개발 산물 중 제초제(glyphosate) 저항성 유전자(modified 5-enolpyruvylshikimate-3-phosphate synthase, epsps)를 도입한 제초제 저항성 콩은 북미지역을 시작 으로 아르헨티나, 브라질 등 여러 나라에서 재배되고 있다. 1996 년에 상업적 재배가 시작된 생명공학작물(Genetically modified crops)은 식품가공용 및 사료용을 주축으로 전 세계 40개국에서 26작물 363이벤트가 승인되었으며, 2015년에는 1억 7,970만 헥타르의 면적에서 재배되었고, 생명공학작물 종자의 세계 시장 규모도 153 억 달러에 이르고 세계 종자 시장의 $20 \%$ 를 달한 것으로 농업생명공학 응용을 위한 국제서비스(ISAAA 2015)는 
보고하고 있다. 유전자변형(Genetically Modified, GM) 콩은 전 세계 9,210만 헥타르의 면적에서 재배되고 있으며, 전 세계 콩 재배면적(11,100만 ha)의 $83 \%$ 를 차지하고 있다(James 2015). 국내에서도 기능성 GM 콩을 개발했다는 보고는 있으나 아직까지 실용화 단계까지는 도달하지 못하고 있다(Oh et al. 2016).

콩에 함유되어있는 토코페롤은 대부분 $\gamma$-토코페롤이며 비타 민 $\mathrm{E}$ 활성이 높은 $\alpha$-토코페롤 함량은 낮아 이를 개선하고자 $\gamma$-토코페롤을 $\alpha$-토코페롤로 전환하는데 작용하는 들깨 유래 $\gamma$-TMT ( $\gamma$-tocopherol methyltransferase) 효소 유전자를 종자 에서 발현되도록하여 $\alpha$-토코페롤 함량을 높인 비타민 $\mathrm{E}$ 강화콩 을 최근 국내에서 개발하였다(Lee et al. 2011a).

생명공학작물의 개발과 상용화에 있어 재배 농경지 및 주변 생태계에 미치는 영향과 위해성 평가는 필수적으로 요구되고 있다(Oh et al. 2014). 생태계의 위해성 평가는 생태계를 유지하 는 생물종을 정량적으로 분석하는 생물다양성 조사가 그 시발점 이며, 생물다양성은 특정 생태계에서 종의 수와 형태, 분포 등의 종 상호간 관계를 나타내는 종다양성(Species diversity), 서식지 내의 경쟁 또는 공생하며 먹이사슬을 형성하는 생태적 기능을 나타내는 생태계 다양성(Ecosystem diversity)으로 구분한다 (Choi et al. 2015). 백만종이 넘는 곤충 종은 생태가 다양하고 먹이 사슬에서도 양적으로 우위를 차지하고 있으며(Price 1997), 생태계 먹이 사슬의 초기 단계에서 생태계의 특성을 나타내는 지표로서 곤충 종의 구성변화는 장기적인 생태계 변화를 분석함 에 중요한 요소이다(Gullan \& Cranston 2005). 작물 재배 안정 성 증대하고, 고부가가치의 기능성 농산물 생산으로 농산물 수요 시장의 다변화 요구 등으로 생명공학작물의 개발 건수와 재배면 적이 증가하고 있는 만큼 개발된 생명공학작물의 실용화를 위해 서는 작물 재배환경 수준의 위해성 평가에 대한 필요성이 요구된 다(Dunwell 1999).

다변량 분석법 중 하나인 주성분 분석은 다수의 변수 간의 변화를 소수의 독립적인 요인들(주성분)로 해석하는 통계 기법 으로 복잡한 데이터의 차원수를 줄여 자료 해석이 훨씬 쉽도록 해준다(Barker et al. 2003). 즉, 다차원의 공간에서 변수들의 분산을 가장 잘 나타내는 소수의 축을 찾아, 변수들의 분포 정보 를 최대한 포함하는 주성분을 보여주는 분석법이다. 복잡한 분석 데이터를 해석하고 유용한 정보를 도출하는데 효율적인 주성분 분석법은 작물이 갖는 고유색에 따른 대사체 프로파일의 차이를 찾아내거나 (Park et al. 2013), 다품종을 대상으로 기능성 성분의 함량에 따른 품질을 평가하는 연구 등에 적용되었다(Park et al. 2012). 최근에는 유전자 재조합에 의해 작물의 성분 변화가
발생하는지를 모품종과 비교하는 연구에 주성분 분석법이 활용 되고 있으며, 유전형질 보다는 재배 시의 자연환경이 작물 성분의 변이성에 더 크게 영향을 미친다는 연구결과가 보고 되었다 (Park et al. 2015, Kim et al. 2016).

$\mathrm{GM}$ 벼 재배 시에 발생하는 해충 양상 및 곤충상 비교에 대한 보고들은 있으나 (Kim et al. 2010, Oh et al. 2014, Choi et al. 2015), 비타민 E 강화콩(1208-3-30)의 환경위해성 평가는 2011년 시작되어 아직 그 결과가 미비하다. 최근 비타민 $\mathrm{E}$ 강화 콩(1208-3-30)의 기능 검정과 토양미생물 위해성 검정에 대한 보고가 있으나 (Lee et al. 2011a, Lee et al. 2011b), 생명공학작 물의 환경위해성평가 항목 중에 하나인 'LMO포장에서 주요 해충의 발생 조사 및 분석’에 관한 연구는 보고 된바 없다. 이에 본 연구에서는 재배환경에서 $\mathrm{GM}$ 콩이 거미를 포함한 해충과 천적 등에 미치는 영향을 평가하기 위해, 비타민 $\mathrm{E}$ 강화콩 (1208-3-30)과 모본인 Willams 82 및 재배품종인 서리태를 재배한 LMO 포장에서 곤충 변화 양상을 비교 분석하였으며, 생명공학작물의 환경 위해성 평가를 위한 기초 자료로 제공하고 자 본 연구를 수행하였다.

\section{재료 및 방법}

본 연구의 시험재료인 비타민 E 강화콩(1208-3-30, 국립농업 과학원)과 Willams 82(국립농업과학원) 및 서리태(국립농업과 학원)를 2015년에 국립농업과학원 LMO 격리 포장(RDA-가 AB-2013-041)에서 난괴법으로 3반복 배치하였다(Lee et al. 2011a). 재배방법은 농촌진흥청의 농사시험 표준재배법을 기준 으로 하였으며, 공시계통인 비타민 E 강화콩(1208-3-30)와 Willams 82 및 서리태의 종자를 500 립씩 50공 트레이에 5 월 14 일에 파종한 후 6월 4일에 $\mathrm{LMO}$ 격리포장에 정식하였다.

곤충 조사는 비타민 E 강화콩(1208-3-30)과 Willams 82 및 서리태를 대상으로 Willams 82 품종의 성장기 (2015년 8월 27일)부터 수확 직전 (2015년 10월 8일)까지 2주 간격으로 총 4 회에 걸쳐 실시하였다. 채집은 각 품종별 3 반복으로 수행하였 고, 비타민 E 강화콩(1208-3-30)과 Willams 82 및 서리태 간의 해충과 천적, 일반 곤충을 대상으로 기능군별 발생양상을 분석하 였다. 각 조사 구역별 채집조사는 실험구내를 총채벌레와 같은 미소 곤충이 포집될 수 있는 채집망을 부착한 지름 9인치 엔진식 흡충기(Agricultural Backpack 2-Cycle Aspirator, John W. Hock Company)로 왕복 이동하면서 각 실험구의 1 반복당 132 주씩 상하단 부위를 훓는 식으로 흡충한 후, 실험구별로 채집물을 
Table 1. Agronomic traits and morphological characteristics of soybean variety. GM 1208-3-30, vitamin E enhanced transgenic soybean; Williams 82, parent cultivar; Seoritae, black soybean variety.

\begin{tabular}{ccccccccccccc}
\hline $\begin{array}{c}\text { Soybean } \\
\text { variety }\end{array}$ & $\begin{array}{c}\text { Stem } \\
\text { length } \\
(\mathrm{cm})\end{array}$ & $\begin{array}{c}\text { No. of } \\
\text { nodes }\end{array}$ & $\begin{array}{c}\text { No. of } \\
\text { branches }\end{array}$ & $\begin{array}{c}\text { No. of } \\
\text { Pods }\end{array}$ & $\begin{array}{c}100 \text { grains } \\
\text { weight }(\mathrm{g})\end{array}$ & $\begin{array}{c}\text { Lodging } \\
(0 \sim 9)\end{array}$ & Growth habit & $\begin{array}{c}\text { Flower } \\
\text { color }\end{array}$ & Leaf shape & $\begin{array}{c}\text { Seed } \\
\text { coat } \\
\text { color }\end{array}$ & $\begin{array}{c}\text { Hilum } \\
\text { color }\end{array}$ \\
\hline $\begin{array}{c}\text { GM } \\
\text { 1208-3-30 }\end{array}$ & 121.3 & 25 & 24.3 & 305.0 & 19.5 & 0 & Indeterminate & White & Lanceolate & Yellow & Black \\
William 82 & 111.3 & 23.4 & 23.7 & 313.0 & 19.8 & 0 & Indeterminate & White & Lanceolate & Yellow & Black \\
Seoritae & 62.4 & 5.5 & 16.7 & 111.5 & 40.1 & 6 & Determinate & Purple & Oval & Black & Black \\
\hline
\end{tabular}

지퍼팩에 담아 에틸 아세테이트(Ethyl Acetate)로 살충하였다.

채집된 곤충은 기능별로 해충군, 천적곤충군(거미 포함) 및 일반 곤충으로 크게 구분하여 계수하였고, 각 기능군별로는 종 수준에서 동정하였다. 비타민 E 강화콩(1208-3-30)와 Willams 82 및 서리태의 품종별 3반복씩 채집된 곤충 조사결과에 대한 통계적 분석은SPSS(23.0.0 for Windows, Rel.23.0, 2015. Chicago: SPSS Inc.)를 이용하여 $p<0.05$ 수준으로 ANOVA와 Ducan test로 평균간의 유의성 여부를 검정하였고, 실험구별 채집된 곤충에 대하여 우점도 지수(dominance index, DI; McNaugton's dominace index) (McNaugton, 1967) 및 풍부도 지수(richness index, RI; Margalef species richness index) (Margalef, 1958), 다양도 지수(diversity index, $\mathrm{H}^{\prime}$; Shannon-Weaver diversity index) (Pielou, 1969), 균등도 지수 (evenness index, EI; Pielou index)를 계산하였다(Pielou, 1975, Choi et al. 2015). 또한 품종 간의 전체 곤충상 변이를 분석하기 위해 주성분 분석법을 사용하였다 (SIMCA-P version 12.0; Umetrics, Umeå, Sweden).

\section{결과 및 고찰}

$\mathrm{GM}$ 콩의 환경위해성 평가 연구를 위해서 비타민 $\mathrm{E}$ 강화콩 (1208-3-30)과 Willams 82 및 서리태를 재배한 포장에서 총 4 회에 걸쳐 채집한 해충, 천적 및 일반곤충의 기능군별 발생현황 을 비교 분석하였다. 본 실험에서 사용된 비타민 $\mathrm{E}$ 강화콩의 모품종인 Williams 82는 미국 품종의 중생종이며, 서리태는 재래 품종의 만숙종으로 구분된다. 세부적인 콩의 특성으로는 서리태의 경장은 $62.4 \mathrm{~cm}$, 절수 5.5 개, 분지수 16.7 개, 협수 111.5 개, 100 립중 $40.1 \mathrm{~g}$, 도복은 6 이며, 잎형은 환형, 화색은 자색, 종피는 검정색, 제색은 검정색이다. 또한, 서리태는 파종 후 개화기가 67 일이며, 파종부터 성숙이 완료 되는데 걸리는
시간이 164 일이며, 첫서리를 맞고서야 잎이 떨어질 정도로 개화 및 성숙이 늦은 특성이 있다(Song et al. 2010). 비타민 E 강화콩 과 모품종인 Williams 82 의 경장은 $111 \sim 121 \mathrm{~cm}$, 절수 23.4 25 개, 분지수 23.7 24.3개, 협수 305 313개, 100 립중 19.5 19.8 $\mathrm{g}$ 이며 도복은 0 였으며, 잎은 모양은 피침형(lanceolate)이었으 며, 화색은 하얀색, 종피색은 노란색, 제색이 검정색으로 나타났 다(Table 1). 콩 줄기의 생육 형태에 따라 3 개의 신육형으로 분류되는데, 대한민국에서 재배되는 장려품종과 재래종의 대부 분은 유한신육형(determinate type)이지만 비타민 $\mathrm{E}$ 강화콩과 Williams 82는 무한신육형(indeterminate type)으로 개화가 시 작된 뒤에도 영양생장이 계속되어 주경 및 분지의 신장과 잎의 전개가 계속되는 특징을 보였다(Lee, 2011). 위와 같은 생육의 차이가 보이는 비타민 E 강화콩과 Williams 82 , 서리태 품종들이 동일 지배지에서 생육 특성의 차이에 의한 품종간의 곤충상 변화와 non-GM/GM콩 품종 간의 곤충상 변화 유무를 확인해 보고자 본 실험의 실험 재료로 이용하였다. 조사기간 동안 8 목 42 과 77 종 17,717 개체의 곤충류와 거미류가 채집되었으며, 기 능군별로는 해충류 38 종, 천적류 15 종, 기타 곤충류 24종이 채집되었다. 품종별로 비타민 $\mathrm{E}$ 강화콩 재배지에서 5,250 개체, 모품종인 Willams 82 재배지는 5,510개체 및 재배품종인 서리 태에서 6,957 개체가 채집되었다(Table 2).

조사기간 동안 채집된 개체들은 기능군별로 해충군(Insect pests), 천적군(Natural enemies), 기타 곤충군(Other insects)으 로 크게 구분하여 계수하였다. 채집된 전체 개체에서 기능군별 비중은 해충 $13.7 \%$, 천적 $5.9 \%$, 기타곤충 $80.3 \%$ 로, 조사기간 동안에 기타 곤충의 발생밀도가 매우 높았다. 해충으로는 실노린 재(Yemma exilis), 각시실노린재(Metacanthus pulchellus), 톱 다리개미허리노린재(Riptortus clavatus) 등 노린재류와 막대애 매미충(Empoasca rybiogon) 등 매미충류의 발생량이 매우 높았 다. 천적으로는 고치벌(Braconidae), 맵시벌(Ichneumonidae) 
Table 2. Total number of common plant dwelling insects and arachnids captured using vacuum suction at fields planted with three different genotypes of soybean at Jeonju, Korea. GM 1208-3-30, vitamin E enhanced transgenic soybean; Williams 82, parent cultivar; Seoritae, black soybean variety.

\begin{tabular}{|c|c|c|c|c|c|c|}
\hline Category & Order & Family & Species & GM 1208-3-30 & Williams 82 & Seoritae \\
\hline & \multirow{4}{*}{ Orthoptera } & Tettigoniidae & Phaneroptera falcata & 0 & 1 & 0 \\
\hline & & Oecanthidae & Oecanthus longicauda & 0 & 1 & 0 \\
\hline & & \multirow{2}{*}{ Acrididae } & Oxya chinensis & 0 & 0 & 1 \\
\hline & & & Acrida cinerea & 0 & 1 & 0 \\
\hline & \multirow{14}{*}{ Hemiptera } & \multirow{2}{*}{ Miridae } & Adelphocoris suturalis & 4 & 5 & 20 \\
\hline & & & Apolygus lucorum & 0 & 2 & 1 \\
\hline & & \multirow{2}{*}{ Berytidae } & Metacanthus pulchellus & 224 & 236 & 22 \\
\hline & & & Yemma exilis & 328 & 352 & 42 \\
\hline & & \multirow{2}{*}{ Coreidae } & Cletus punctiger & 3 & 0 & 3 \\
\hline & & & Riptortus clavatus & 34 & 37 & 47 \\
\hline & & & Paromius exiguus & 1 & 0 & 0 \\
\hline & & Lygaeidae & Panaorus albomaculatus & 0 & 0 & 1 \\
\hline & & & Nysius plebejus & 3 & 5 & 0 \\
\hline & & & Piezodorus hybneri & 11 & 31 & 11 \\
\hline & & & Dolycoris baccarum & 1 & 4 & 1 \\
\hline & & Pentatomidae & Homalogonia obtusa & 0 & 1 & 0 \\
\hline & & & Palomena angulosa & 0 & 3 & 3 \\
\hline & & & Nezara antennata & 4 & 1 & 10 \\
\hline \multirow[t]{21}{*}{ Insect pests } & \multirow{3}{*}{ Homoptera } & Cicadellidae & Cicadella viridis & 3 & 4 & 2 \\
\hline & & Typhlocybinae & Empoasca rybiogon & 99 & 126 & 267 \\
\hline & & Ricaniidae & Ricania taeniata & 1 & 0 & 0 \\
\hline & \multirow{3}{*}{ Coleoptera } & Rutelidae & Popillia mutans & 0 & 0 & 1 \\
\hline & & \multirow{2}{*}{ Chrysomelidae } & Medythia nigrobilineata & 54 & 81 & 141 \\
\hline & & & Monolepta quadriguttata & 7 & 10 & 12 \\
\hline & \multirow{6}{*}{ Diptera } & \multirow{4}{*}{ Platystomatidae } & Rivellia flaviventris & 16 & 21 & 9 \\
\hline & & & Rivellia alini & 1 & 0 & 0 \\
\hline & & & Rivellia apicalis & 5 & 5 & 12 \\
\hline & & & Chromatomyia horticola & 0 & 1 & 0 \\
\hline & & \multirow[t]{2}{*}{ Agromyzidae } & Melanagromyza sojae & 8 & 1 & 6 \\
\hline & & & Liriomyza congesta & 5 & 0 & 5 \\
\hline & Hymenoptera & Tenthredinidae & Athalia proxima & 1 & 1 & 0 \\
\hline & \multirow{7}{*}{ Lepidoptera } & Tortricidae & Phalonidia curvistrigana & 0 & 0 & 3 \\
\hline & & Nolidae & Celama taeniata & 0 & 0 & 1 \\
\hline & & Noctuidae & Spodoptera litura & 0 & 0 & 6 \\
\hline & & Geometridae & Scopula superior & 0 & 0 & 1 \\
\hline & & \multirow{3}{*}{ Pyralidae } & Ostrinia zaguliaevi & 0 & 0 & 1 \\
\hline & & & Omiodes indicatus & 0 & 0 & 4 \\
\hline & & & sp. & 7 & 18 & 29 \\
\hline & \multicolumn{2}{|c|}{ Subtotal } & & & 948 & 662 \\
\hline
\end{tabular}




\begin{tabular}{|c|c|c|c|c|c|c|}
\hline Category & Order & Family & Species & GM 1208-3-30 & Williams 82 & Seoritae \\
\hline \multirow{16}{*}{ Natural enemies } & \multirow[t]{2}{*}{ Hemiptera } & Nabidae & Nabis stenoferus & 3 & 0 & 6 \\
\hline & & Lygaeidae & Geocoris (Piocoris) varius & 2 & 3 & 1 \\
\hline & \multirow{2}{*}{ Neuroptera } & \multirow{2}{*}{ Chrysopidae } & Cunctochrysa albolineata & 30 & 33 & 8 \\
\hline & & & Chrysopa pallens & 0 & 2 & 2 \\
\hline & \multirow{3}{*}{ Coleoptera } & \multirow{3}{*}{ Coccinellidae } & Harmonia axyridis & 1 & 2 & 1 \\
\hline & & & Propylea japonica & 3 & 1 & 2 \\
\hline & & & Coccinella septempunctata & 0 & 0 & 2 \\
\hline & \multirow{7}{*}{ Hymenoptera } & Chalcididae & Brachymeria lasus & 10 & 6 & 2 \\
\hline & & Eulophidae & sp. & 0 & 3 & 0 \\
\hline & & \multirow{3}{*}{ Braconidae } & Cotesia glomeratus & 0 & 0 & 1 \\
\hline & & & Meteorus pulchricornis & 18 & 20 & 58 \\
\hline & & & sp. & 68 & 101 & 330 \\
\hline & & \multirow{2}{*}{ Ichneumonidae } & Euceros rufocinctus & 0 & 0 & 1 \\
\hline & & & sp. & 24 & 32 & 37 \\
\hline & \multicolumn{3}{|c|}{ Arachnida } & 54 & 63 & 123 \\
\hline & \multicolumn{2}{|c|}{ Subtotal } & & 213 & 266 & 574 \\
\hline \multirow{25}{*}{ Other insects } & \multirow{4}{*}{ Homoptera } & \multirow{3}{*}{ Cicadellidae } & Singapora shinshana & 6 & 2 & 2 \\
\hline & & & Macrosteles striifrons & 226 & 208 & 470 \\
\hline & & & sp. & 37 & 27 & 25 \\
\hline & & Membracidae & Tricentrus yagoi & 0 & 1 & 0 \\
\hline & Neuroptera & Hemerobiidae & sp. & 0 & 1 & 1 \\
\hline & \multirow{2}{*}{ Coleoptera } & \multirow{2}{*}{ Chrysomelidae } & Syneta adamsi & 0 & 1 & 0 \\
\hline & & & Physosmaragdina nigrifrons & 0 & 0 & 1 \\
\hline & \multirow{17}{*}{ Diptera } & Chironomidae & sp. & 873 & 1,181 & 1,337 \\
\hline & & Stratiomyidae & Microchrysa flaviventris & 8 & 10 & 9 \\
\hline & & Dolichopodidae & $\mathrm{sp}$. & 12 & 21 & 38 \\
\hline & & \multirow{2}{*}{ Mycetophilidae } & Acnemia braueri & 0 & 2 & 2 \\
\hline & & & sp. & 0 & 5 & 69 \\
\hline & & Syrphidae & Sphaerophoria menthastri & 0 & 0 & 3 \\
\hline & & \multirow[t]{2}{*}{ Chloropidae } & Elachiptera insignis & 2,962 & 2,710 & 3,556 \\
\hline & & & Chlorops oryzae & 0 & 1 & 0 \\
\hline & & \multirow{3}{*}{ Lauxaniidae } & Minettialongipennis & 6 & 10 & 18 \\
\hline & & & sp. & 10 & 16 & 41 \\
\hline & & & Steganopsis melanogaster & 14 & 14 & 27 \\
\hline & & Drosophilidae & sp. & 1 & 11 & 14 \\
\hline & & Anthomyiidae & Delia platura & 5 & 0 & 0 \\
\hline & & \multirow{2}{*}{ Muscidae } & Atherigona sp. & 9 & 13 & 3 \\
\hline & & & sp. & 2 & 2 & 5 \\
\hline & & Calliphoridae & sp. & 46 & 59 & 100 \\
\hline & & Sarcophagidae & Boettcheriscaperegrina & 0 & 1 & 0 \\
\hline & \multicolumn{2}{|c|}{ Subtotal } & & 4,217 & 4,296 & 5,721 \\
\hline Total & & & & 5,250 & 5,510 & 6,957 \\
\hline
\end{tabular}

등의 기생성 곤충류와 흰띠풀잠자리(Cunctochrysa albolineata) 등의 포식성 곤충 및 거미류(Araneae)가 조사되었으며, 이 중에 벌류와 거미류의 밀도가 높았다. 기타 곤충에서는 별노랑굴파리 류(Elachiptera insignis), 깔다구(Chironomidae) 등 파리목 (Diptera)의 곤충이 $74.7 \%$ 로 대부분을 차지하였다(Fig. 1). 기능군별 곤충 발생 양상 비교를 위하여 조사기간 동안 해충,
천적, 기타 곤충군으로 구분하여 비타민 $\mathrm{E}$ 강화콩 재배가 곤충 발생 양상에 미치는 영향을 분석하였다. 해충군, 천적군 및 기타 곤충의 개체군 밀도는 비타민 $\mathrm{E}$ 강화콩과 Willams 82 재배지에 서는 비슷한 수준으로 발생하였다. 재배 품종인 서리태 품종에서 는 해충과 천적군의 개체 밀도가 비타민 $\mathrm{E}$ 강화콩과 비교하여 통계적으로 유의한 차이가 보였으나, 기타 곤충군과 전체 채집된 


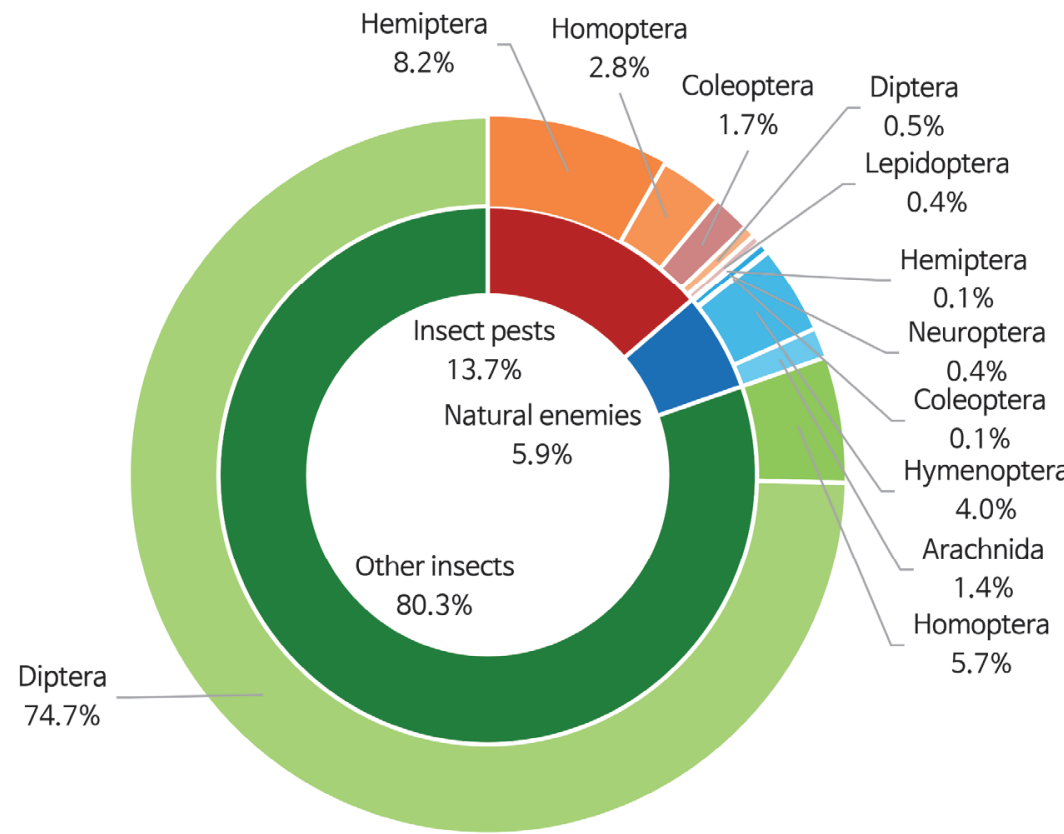

Fig. 1. Occurrences of common plant dwelling insects and arachnids captured using vacuum suction on three different genotypes of soybean.

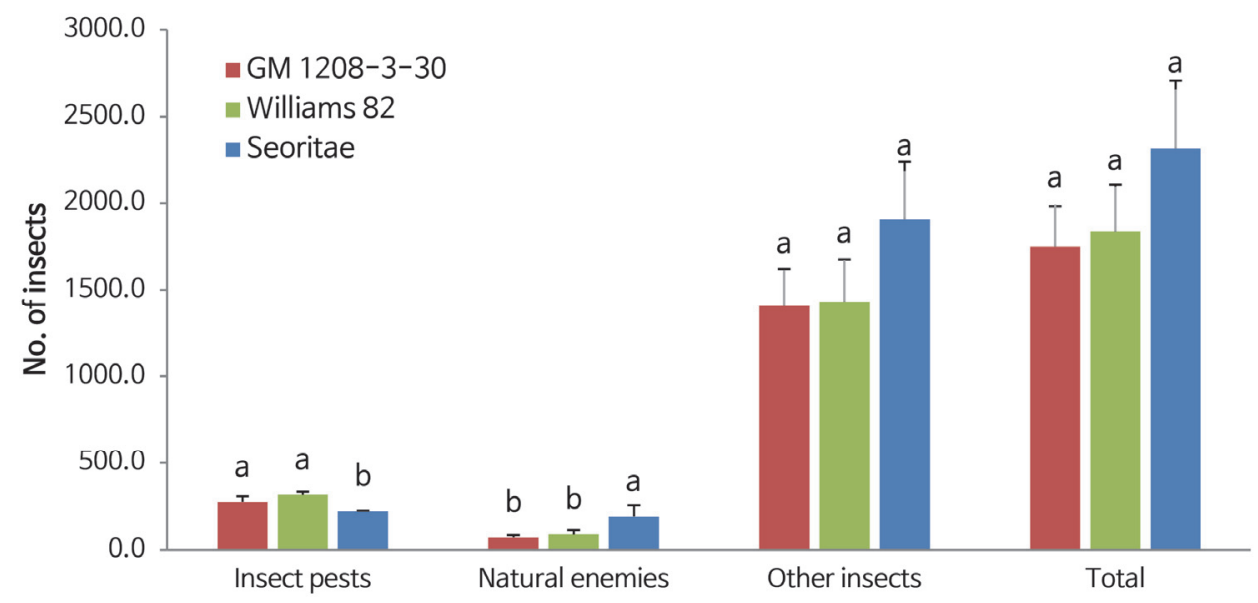

Fig. 2. Aberage population densities of insect groups by soybean variety in LMO field. (Duncan's Multiple Range Test at $p<0.05$ within category).

곤충류에서는 통계적 유의성을 보이지 않았다(Fig. 2).

조사기간 동안 재배 포장에서 해충류의 발생은 총 7 목 38 종의 해충이 조사되었고, 채집된 전체 해충류에서 노린재목(Hemiptera) 이 59.71\%로 우점하였으며, 매미목(Homoptera) $20.66 \%$, 딱정 벌레목(Coleoptera) $12.59 \%$, 파리목(Diptera) 3.91\%, 나비목 (Lepidoptera) 2.88\%, 메뚜기목(Orthoptera) 0.16\%, 벌목 (Hymenoptera) $0.08 \%$ 로 조사되었다. 비타민A 강화콩과
Willams 82 및 서리태 재배 품종 간의 메뚜기목, 파리목, 벌목에 서는 통계적 유의성은 없었다. 노린재목, 매미목, 딱정벌레목에서 비타민 E 강화콩과 Willams 82 간에는 통계적 유의성이 없으나 서리태 재배지의 채집된 개체와는 통계적으로 유의차가 있었다 (Fig. 3). 천적류의 발생은 총 5목 15종였으며, 벌목(Hymenoptera) $67.52 \%$ 로 우점하였고, 거미류(Arachnida) 22.79\%, 풀잠자리목 (Neuroptera) $7.12 \%$, 노린재목(Hemiptera) $1.42 \%$, 딱정벌레목 


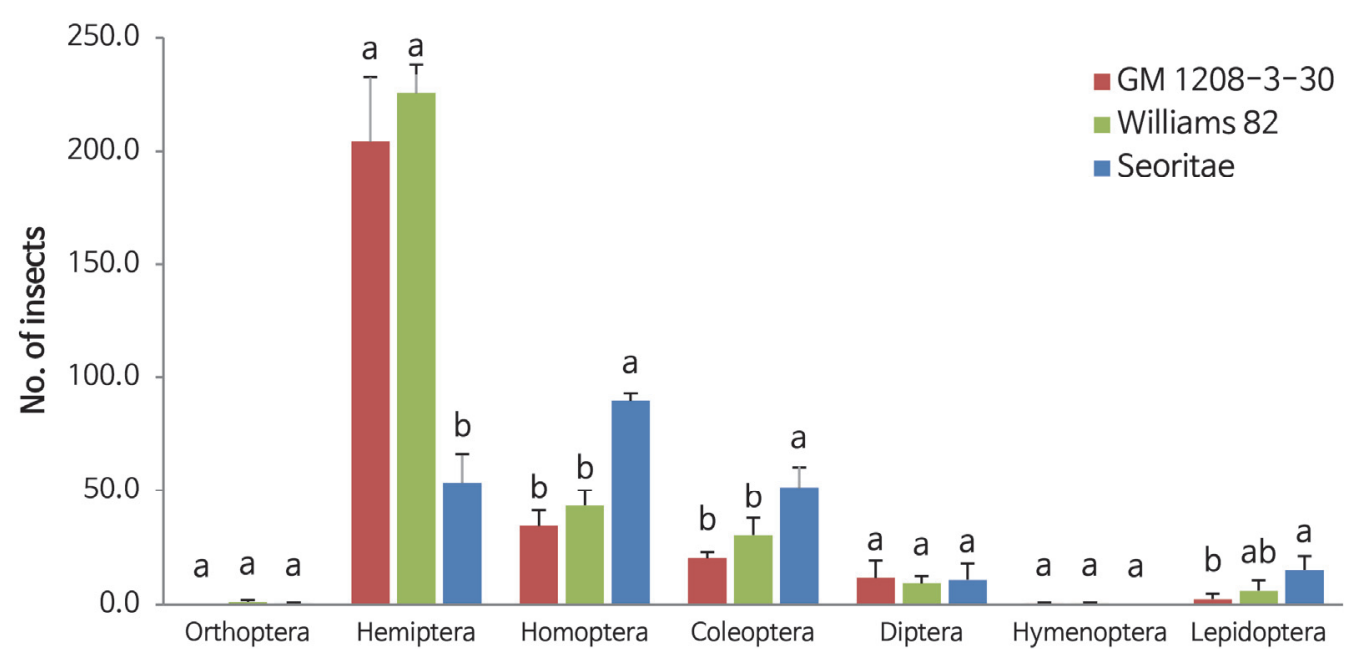

Fig. 3. Aberage population densities of insect pests by soybean variety in LMO field. (Duncan's Multiple Range Test at $p<0.05$ within order).

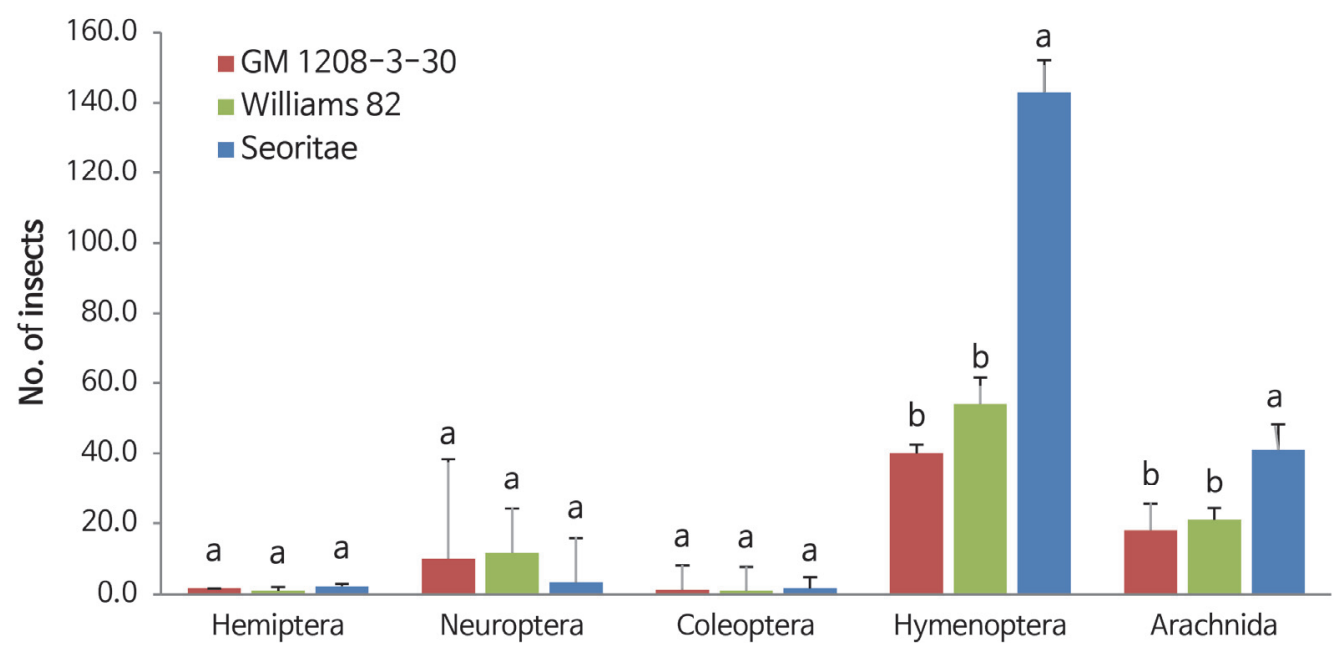

Fig. 4. Aberage population densities of natural enemies by soybean variety in LMO field. (Duncan's Multiple Range Test at $p<0.05$ within order).

(Coleoptera) $1.14 \%$ 의 비율로 조사되었다. 비타민 E 강화콩과 Willams 82 및 서리태 품종간의 통계적 유의 차이는 노린재목, 풀잠자리목, 딱정벌레목에서는 없었으나, 벌목과 거미류에서는 서리태가 비타민 E 강화콩과 Willams 82에 통계적으로 유의차 가 있었다(Fig. 4). 하지만, 벌목과 거미류 모두에서 비타민 E 강화콩과 Willams 82 간에 유의한 차이는 나타나지 않았다. 해충과 천적류를 제외한 기타 곤충류의 발생 조사 결과, 총 4 목 24종의 곤충이 채집되었으며, 파리목(Diptera)이 $92.92 \%$ 로 대 다수를 차지하였고, 매미목(Homoptera) $7.06 \%$, 풀잠자리목 (Neuroptera) $0.01 \%$, 딱정벌레목(Coleoptera) $0.01 \%$ 로 조사되 었다. 비타민 $\mathrm{E}$ 강화콩과 Willams 82 및 서리태 품종간의 통계적
유의 차이는 파리목, 풀잠자리목, 딱정벌레목에서는 없었고, 매미 목에서 비타민 E 강화콩과 Willams 82 간에는 통계적 유의성이 없으나 서리태 품종과는 통계적으로 유의차가 있었다(Fig. 5). 정리하면, 비타민 $\mathrm{E}$ 강화콩은 재배품종인 서리태와 해충군, 천적 군, 기타 곤충군의 발생 밀도에 차이를 보였으나, 이 결과는 모품종인 Willams 82에서도 동일하였기 때문에 비타민 E 강화 콩이 모본과 비교하여 기능군별 곤충상 발생에 특이적인 영향을 미치지 않는 것으로 판단되었다.

비타민 E 강화콩과 Willams 82 및 서리태를 재배시에 시기별 곤충 발생 양상에 차이가 나타나는지를 분석하였다. 개체군의 밀도는 세 품종 모두에서 첫 채집일인 8월 27일에 가장 낮았으며, 


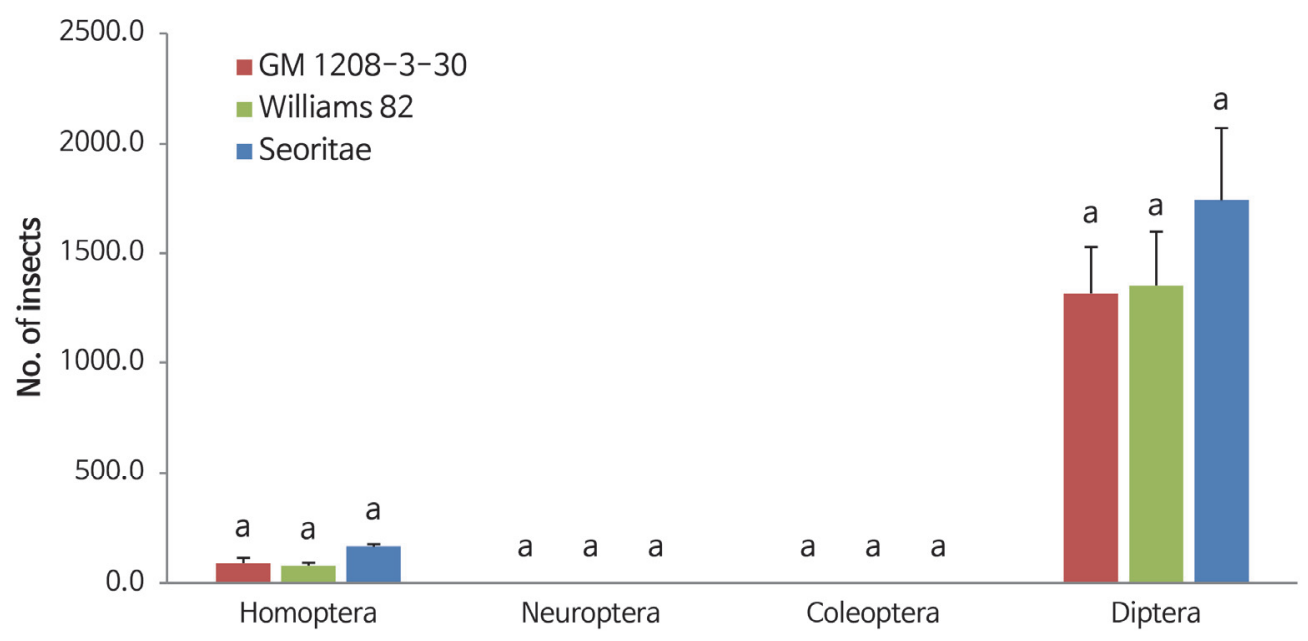

Fig. 5. Aberage population densities of other insects by soybean variety in LMO field. (Duncan's Multiple Range Test at $p<0.05$ within order).

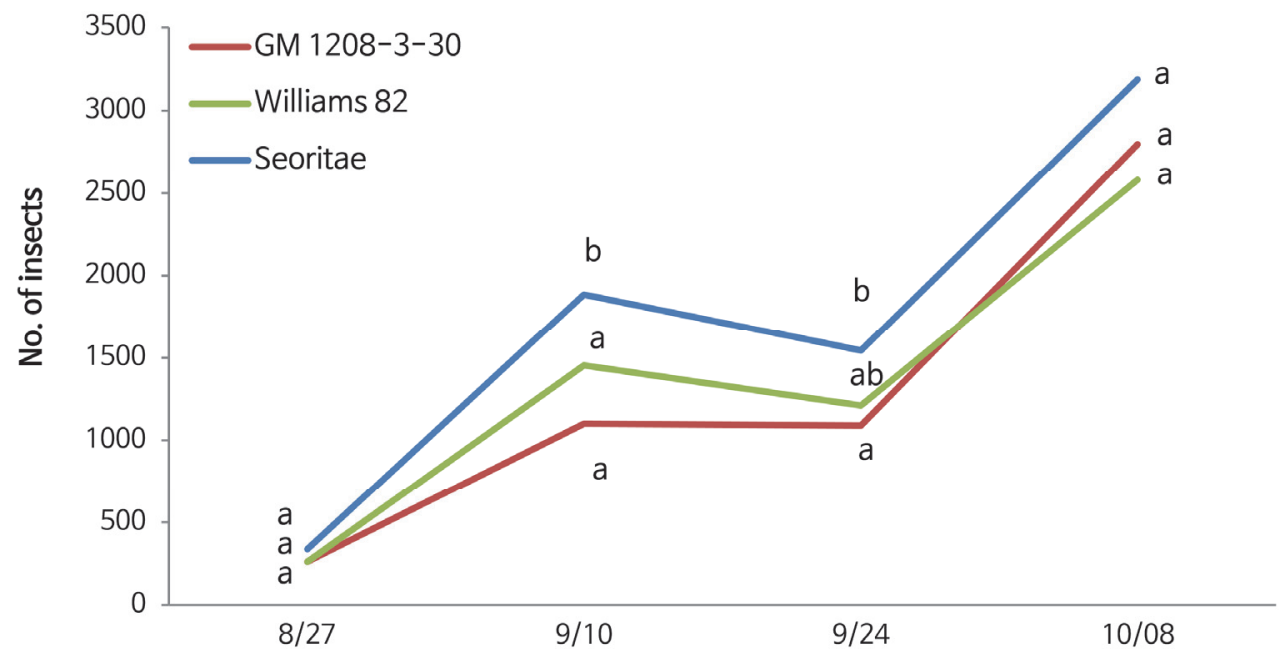

Fig. 6. Seasonal fluctuations of common plant dwelling insects by soybean variety. (Duncan's Multiple Range Test at $p<0.05$ ).

9월 10 에 개체군 밀도가 증가하였다가 9월 24일에 다소 감소한 경향을 보였으며, 마지막 채집일인 10 월 8 일이 가장 높은 개체군 밀도를 보였다. 비타민 E 강화콩과 모품종인 Willams 82간의 시기별 개체군 밀도의 통계적인 유의성이 보이지 않았으나, 비타 민 $\mathrm{E}$ 강화콩과 재배 품종인 서리태에서는 9월 10일과 9월 24일에 통계적인 유의성을 보였다(Fig. 6). 하지만 이러한 차이는 Williams 82와의 비교에서도 동일하게 나타났다. 즉, 비타민 $\mathrm{E}$ 강화콩과 모품종인 Willams 82 에서 4회의 채집 시기별 곤충의 발생 밀도 차이는 보이지 않았으며, 따라서 비타민 $\mathrm{E}$ 강화콩이 시기별 곤충상 발생에도 특별한 영향을 미치지 않는 것으로 판단되었다.
채집된 곤충상의 군집 분석을 전체 채집된 곤충에서 우점도 지수(DI)는 최소 0.70 에서 최대 0.73 로 매우 높았는데 이는 별노랑굴파리(Elachiptera insignis)의 개체수가 다른 종에 비해 현저히 많이 채집되었기 때문이었다. 풍부도 지수(RI)는 콩 품종 별로 Willams 82와 서리태 재배 포장에서 각각 5.28, 5.30를 보여 비타민E 강화콩 포장의 4.74보다 조금 높게 나타났으나, 유의성은 없었다. 다양도 지수 $\left(\mathrm{H}^{\prime}\right)$ 는 각 콩 재배 포장에서 $1.67 \sim 1.85$ 의 값으로 품종간 유의성은 없었으며, 이 결과는 군집 의 다양도가 다소 떨어지는 결과로 앞서 우점도 지수와 비교해보 면 대체적으로 일부 종의 채집개체수가 매우 높았음을 알 수 있다. 습지와 같이 종 다양도가 풍부한 지역에서 약 2.7 4.0 
Table 3. Community analysis of insects in LMO field

\begin{tabular}{cccc}
\hline \multirow{2}{*}{ Indices } & \multicolumn{3}{c}{ Soybean variety } \\
\cline { 2 - 4 } & GM 1208-3-30 & Williams 82 & Seoritae \\
\hline Dominance (DI) & $0.73 \pm 0.04^{\mathrm{az}}$ & $0.70 \pm 0.04^{\mathrm{a}}$ & $0.70 \pm 0.00^{\mathrm{a}}$ \\
Richness (RI) & $4.74 \pm 0.22^{\mathrm{a}}$ & $5.28 \pm 0.35^{\mathrm{a}}$ & $5.30 \pm 0.53^{\mathrm{a}}$ \\
Diversity (H') & $1.67 \pm 0.21^{\mathrm{a}}$ & $1.85 \pm 0.12^{\mathrm{a}}$ & $1.81 \pm 0.02^{\mathrm{a}}$ \\
Evenness (EI) & $0.46 \pm 0.06^{\mathrm{a}}$ & $0.50 \pm 0.03^{\mathrm{a}}$ & $0.48 \pm 0.01^{\mathrm{a}}$ \\
\hline
\end{tabular}

${ }^{z}$ Duncan's Multiple Range Test at $p<0.05$ within category.

정도 곤충 군집의 다양도가 나오는 것에 비하면 다소 낮은 값으 로, 이를 통해 콩 재배지역인 밭 포장이 단일 작물 재배 지역의 특징을 나타냄을 알 수 있었다. 또한, 콩 재배포장의 높은 우점도 지수에 비해 다양도 지수와 균등도 지수(EI, 0.46 0.50)가 낮은 것을 통해 대체적으로 일부 종의 채집 개체수가 매우 높았음을 알 수 있었다. 이는 재배한 콩의 종류와는 상관없이 LMO 격리 포장의 생태적 특성과 일부 관계가 있을 것으로 사료되며, 곤충 종 개체의 다양도가 낮고, 특정한 곤충종이 많이 채집되는 등의 단일 품종의 경작지에서 나타나는 특성을 본 연구에서도 확인할 수 있었다(Table 3). 이와 같은 결과는 Choi et al. (2015)가 보고한 $\mathrm{GM}$ 벼 재배시에 발생하는 곤충상 결과와 유사하였다. 호남지역 콩 재배지의 주요 해충 및 천적류에 대해 보고한 Paik et al. (2007)의 결과에서, 비록 LMO 연구 및 실험방법에 차이가 있었지만, 주요 해충의 발생 밀도에서 본 연구와 비슷한 결과를 보였으며, Back et al. (2010)의 제초제 저항성 콩 재배지의 주요 해충에 대한 보고도 유사한 결과를 나타내었다(Paik et al. 2007, Back et al. 2010).

비타민 E 강화콩(1208-3-30)와 Willams 82 및 서리태의 재배 포장에서 총 4회에 걸쳐 채집한 곤충들이 재배된 $\mathrm{GM} / \mathrm{non}-\mathrm{GM}$ 콩의 형질에 따라 곤충상 변이를 보이는지 확인하기 위하여, 곤충상 데이터를 주성분 분석법에 적용하여 통계적 분석을 수행 하였다(Fig. 7). 총 77종의 곤충상 데이터에 대해 주성분 분석을 수행하여 얻은 score plot을 확인한 결과, 비타민 E 강화콩을 재배한 포장의 곤충상은 모품종인 Williams 82 을 재배한 포장의 것과 차이를 보이지 않았다(Fig. $7 \mathrm{~A})$. 하지만, 주성분 1 에 의해 Williams 82와 비타민 E 강화콩의 곤충상은 국내에서 재배하는 콩 품종인 서리태를 재배한 포장에서 나타나는 곤충상과는 확연 하게 구분이 되었다. 이러한 변이를 보이는데 영향을 미친 곤충이 무엇인지 알아보기 위해, 주성분 분석 결과를 loading plot으로 구하고 곤충의 분포를 확인하였다(Fig. $7 \mathrm{~B})$. 채집한 곤충을 해충 과 천척군, 그리고 기타 곤충으로 분류하였을 때, loading plot에
서는 이러한 분류에 따른 곤충상의 분포 차이가 나타나지 않았다. 주성분1에 의해 실노린재(Yemma exilis)와 각시실노린재 (Metacanthus pulchellus)가 plot의 오른쪽에, 꼭지매미충 (Macrosteles striifrons)과 막대애매미충(Asymmetnasea nybiogon), 큰날개파리과(Lauxaniidae)가 왼쪽에 분포하였다. 이 때, 주성분 1 의 고유값(eigenvalue)은 2.48 이었으며 실노린재 와 각시실노린재, 꼭지매미충, 막대애매미충, 큰날개파리과의 주성분1에 대한 고유벡터(eigenvector)는 각각 0.209349 , $0.205614,-0.211008,-0.20591,-0.198273$ 으로 나타났다. 획득 한 곤충상 조사 결과를 보면 Williams 82 와 비타민 E 강화콩을 재배한 포장에는 실노린재와 각시실노린재가 서래태 품종을 재배한 포장보다 상대적으로 밀도가 높았으며, 꼭지매미충, 막대 애매미충 및 큰날개파리과는 비타민 E 강화콩과 Williams 82에 비해 서리태 품종을 재배한 포장에서 상대적으로 많이 발생함을 확인 할 수 있었다(Table 1). 서리태를 재배한 포장의 곤충상의 경우 주성분 2에 의해 반복 간에 분리가 나타났다. 주성분 2의 고유값 (eigenvalue)은 1.57 이었으며, 주성분 2 를 기준으로 가장 오른 쪽에 위치한 곤충은 시골가시허리노린재(Cletus punctiger), 벼메뚜기 (Oxya chinensis), 흰무늬긴노린재(Panaorus albomaculatus)로 이 들의 고유벡터(eigenvector)는 각각 $-0.242784,-0.222872$, -0.222872 으로 나타났다. 실제로 이 3 가지 곤충은 3 반복 중 2 반복에서 채집되지 않았다. 이러한 결과를 통해, 주성분분석법 은 복잡한 데이터로부터 유용한 정보를 얻는데 효과적인 다변량 분석법 중 하나임을 다시 한번 확인 할 수 있었다. 종합하면, 재배한 콩의 품종에 따라 곤충 개체 밀도의 차이가 발생하며 이것은 특이적인 곤충상의 변화에 따른 결과가 아니고 재배한 콩의 품종에 의한 결과임을 확인하였다. 주성분 분석 결과, $\gamma$ -TMT ( $\gamma$-tocopherol methyltransferase) 유전자가 도입된 비타 민 E 강화콩이 모품종과 비교해 재배 포장 내의 곤충상에 영향을 미치지 않음을 확인하였다. 

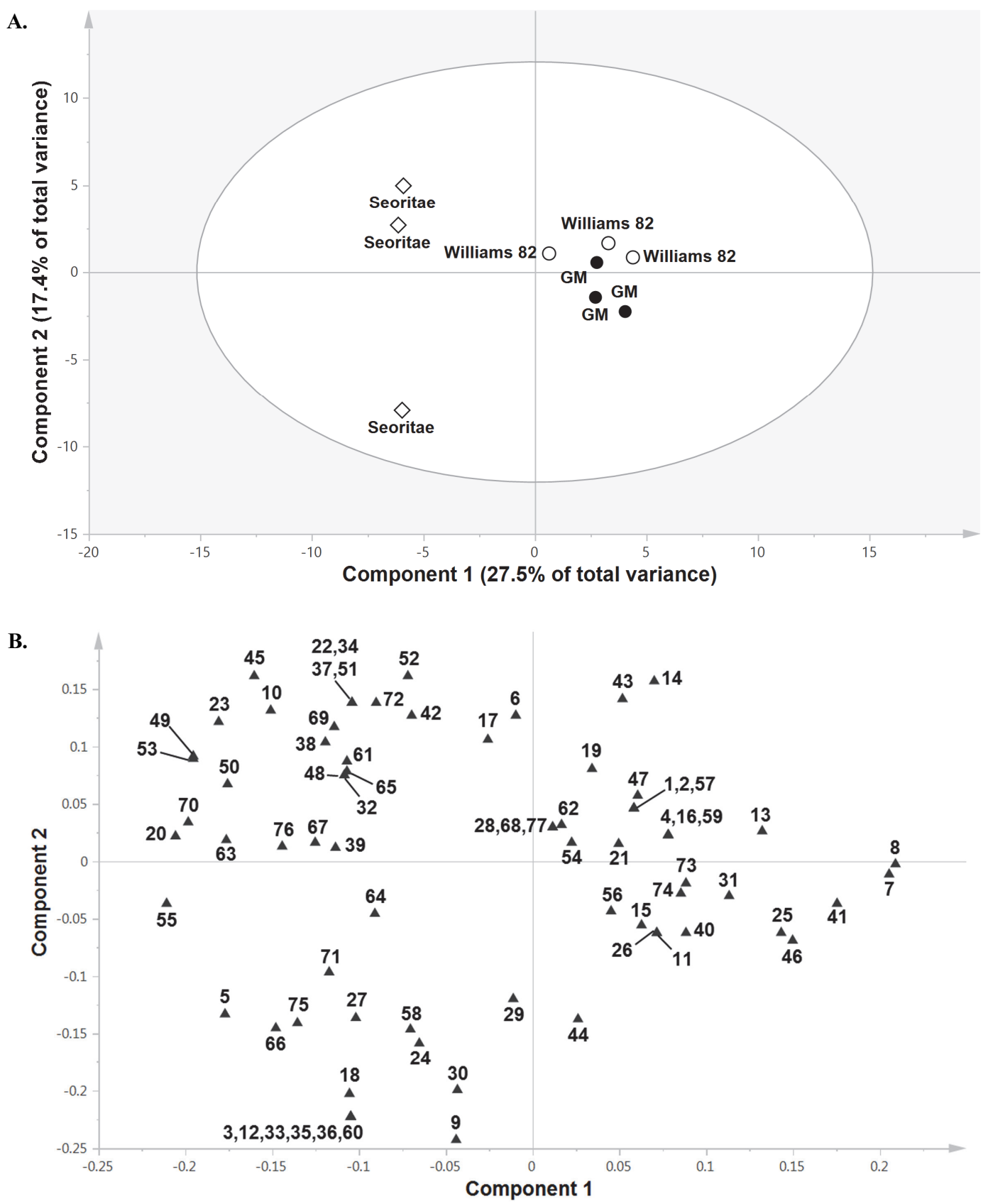

Fig. 7. (A) Score and (B) loading plots of principal components 1 and 2 of the PCA results obtained from data on 77 insects collected at fields planted with three different genotypes of soybean. The numbers of the loading plots represent the same compounds as for Table 1. GM, vitamin E enhanced transgenic soybean; Williams 82, parent cultivar; Seoritae, black soybean variety.

\section{적 요}

본 연구는 들깨 유래 $\gamma$-TMT ( $\gamma$-tocopherol methyltransferase) 효소 유전자를 종자에서 발현시켜 a-토코페롤 함량을 증가시킨 비타민 E 강화콩(1208-3-30)의 환경위해성 평가에 대한 프로토
콜 및 가이드라인을 개발하고자 수행하였다. 국립농업과학원 $\mathrm{LMO}$ 격리포장에서 비타민 $\mathrm{E}$ 강화콩(1208-3-30)과 모품종인 Williams 82 및 재배 품종인 서리태를 재배하고, 성장기와 수확 직전까지의 기간 동안 거미류를 포함한 곤충류의 다양성을 조사 하였다. 조사기간 동안 채집된 개체들은 기능별로 천적군, 해충 
군, 기타 곤충군으로 크게 구분하여 계수하였으며, 총 8 목 42 과 77 종 17,717 개체가 채집되었다. 조사된 개체군의 천적군, 해충 군, 기타 곤충의 밀도는 비타민 E 강화콩(1208-3-30)과 모품종인 Williams 82 간에는 유사한 발생을 보였으나, 재배 품종인 서리 태는 해충군과 천적군의 개체 밀도에서 비타민 $\mathrm{E}$ 강화콩과 Williams 82 모두와 통계적인 유의차가를 보였다. 기타 곤충에 서는 유의적 차이를 보이지 않았다. 시기별 곤충 발생 양상에서도 비타민 E 강화콩(1208-3-30)과 모품종인 Williams 82 간에는 통계적인 유의성을 나타나지 않았으나, 비타민 $\mathrm{E}$ 강화콩과 재배 품종인 서리태에서는 9월 10일과 9월 24일에 통계적인 유의성을 보였다. 이러한 차이는 서리태와 Williams 82 간에도 동일하게 나타났다. 채집된 총 77 종의 곤충상 데이터를 주성분 분석을 한 결과, Williams 82 와 비타민 $\mathrm{E}$ 강화콩의 재배지의 곤충상은 국내에서 재배하는 대표적인 콩 품종인 서리태를 재배한 포장에 서 나타나는 곤충상과는 확연하게 구분이 되었으며, 이는 특이적 인 곤충상의 변화에 따른 결과가 아니고 재배한 콩의 품종인 서리태와 Williams 82 간의 차이에 의한 결과임을 확인하였다. 결과적으로, $\gamma$-TMT ( $\gamma$-tocopherol methyltransferase) 유전자 가 도입된 비타민 $\mathrm{E}$ 강화콩의 재배 시에 해충 및 천적의 개체군 밀도와 발생양상은 모품종인 Williams 82에서와 차이가 없는 것으로 조사되었다.

\section{사 사}

본 연구는 농촌진흥청 연구개발사업(과제번호: PJ01186701, PJ01191107)의 지원에 의해 이루어진 것임.

\section{REFERENCES}

1. Back HJ, Shon SI, Cho MR, Lee GS, Oh YJ, Park JS, Lee KJ, Oh SD, Suh SC, Ryu TH. 2010. Development of Protocol for Analyzing Pollinator Insect-mediated Gene Transfer from GM Crop. Kor. J Intl. Agric. 22: 293-297.

2. Choi WS, Ahn SJ, Yoon JH, Kim HH, Jang JW, Park JJ. 2015. Comparing of insect fauna between transgenic rice and common Rice cultivar based on light tap and sweeping methods. J. Agri. \& Life Sci. 49: 1-17.

3. Dunwell JM. 1999. Transgenic crops: the next generation, or an example of 2020 vision. Ann Bot-London 84: 269-277.

4. Gullan PK, Cranston PS. 2005. The insect an outline of entomology. 519 pp. Blackwell Publishing Ltd. Oxford, UK.

5. James C. 2015. The global Status of Commercialized Biotech/GM Crops: 2015. ISAAA Briefs No. 51.

6. Kim MS, Baek SA, Park SY, Baek SH, Lee SM, Ha SH, Lee YT, Choi J, Im KH, Kim JK. 2016. Comparison of the grain composition in resveratrol-enriched and glufosinate-tolerant rice (Oryza sativa) to conventional rice using univariate and multivariate analysis. J. Food Compos. Anal. 52: 58-67.

7. Kim KM, Ryu TH, Suh SJ. 2010. Studies on insect diversity related to genetically engineered vitamin A rice under large scale production. Kor. J. Breed. Sci. 42: 157-162.

8. Lee KJ. 2011. Development and Characterization of Vitamin E Enhanced Transgenic Soybean. Doctoral dissertation, University of Seoul, Korea.

9. Lee, KJ, Yi BY, Kim KH, Kim JB, Suh SC, Woo HJ, Shin KS, Kweon SJ. 2011a. Development of efficient transformation protocol for soybean (Glycine max L.) and characterization of transgene expression after Agrobacterium-mediated gene transfer. J. Kor. Soc. Appl. Biol. Chem. 54: 37-45.

10. Lee KJ, Shon SI, Lee JY, Yi BY, Oh SD, Kweon SJ, Suh SC, Ryu TH, Kim KH, Park JS. 2011b. Effects of transgenic soybean cultivation on soil microbial community in the rhizosphere. Kor. J. Environ. Agric. 30: 466-472.

11. Margalef DR. 1958. Information theory in ecology. Gen. Syst. 3: 36-71.

12. McNaughton SJ. 1967. Relationship among functional properties of California grassland. Nature, 216: 168-169.

13. Oh SD, Kim JS, Lee KJ, Ryu TH, Suh SJ. 2014. Studies on insect diversity related to drought-tolerant transgenic (Agb0103) rice under large scale GMO field. Kor. J. Breed. Sci. 46: 136-142.

14. Oh SD, Yun DW, Sohn SI, Lee BK, Lee KJ, Chang AC. 2016. Environmental risk assessment and evaluation of vitamin $\mathrm{E}$ enhanced transgenic soybean: Responses of Daphnia magna fed on vitamin E enhanced transgenic soybean. Kor. J Intl. Agric. 28: 197-204.

15. Paik CH, Lee GH, Choi MY, Seo HY, Kim DH, Hwang CY, Kim SS. 2007. Status of the occurrence of insect pests and their natural enemies in soybean fields in Honam Province. Kor. J Appl. Entmol. 46: 275-280.

16. Park SY, Lim SH, Ha SH, Yeo Y, Park WT, Kwon DY, Park SU, Kim JK. 2013. Metabolite profiling approach reveals the interface of primary and secondary 
metabolism in colored cauliflowers (Brassica oleracea L. ssp. botrytis). J. Agr. Food Chem. 61: 6999-7007.

17. Park SY, Park WT, Park YC, Ju JI, Park SU, Kim JK. 2012. Metabolomics for the quality assessment of Lycium chimense fruits. Biosci. Biotech. Bioch. 76: 2188-2194.

18. Park SY, Kim JK, Jang JS, Lee SY, Oh S, Lee SM, Yang CI, Yeo Y. 2015. Comparative analysis of nutritional composition between the disease-resistant rice variety OsCK1 and conventional comparators. Food Sci. Biotech. 24: 225-231.

19. Pielou CE. 1969. Shannon's formula as a measure of specific diversity, its use and misuse. Amer. Nat. 100: 463-465.

20. Pielou CE. 1975. Ecology diversity. Wiley Publ. NY. pp. 165.

21. Price PW. 1997. Insect Ecology, 3rd ed., John Wiley and Sons, New York.

22. Song HS, Kim JB, Lee KJ, Kim DS. Kim SH, Lee SH, Lee SJ, Kang SY. 2010. A new improved soybean variety, 'Josaengseori' by mutation breeding. Kor. J. Breed. Sci. 42: 222-225. 